\title{
The Role of Central Banks in Scaling Up Sustainable Finance - What do Monetary Authorities in the Asia-Pacific Region Think?*
}

\author{
Aziz Durrani, ${ }^{1}$ Ulrich Volz ${ }^{2,3}$ \& Masyitah Rosmin ${ }^{1}$
}

\author{
${ }^{1}$ South East Asian Central Banks (SEACEN) Research and Training Centre \\ ${ }^{2}$ SOAS University of London \\ ${ }^{3}$ German Development Institute
}

Corresponding author: Ulrich Volz, SOAS Centre for Sustainable Finance, SOAS University of London, Thornhaugh Street, London WC1H OXG, UK. Email: uv1@soas.ac.uk

\begin{abstract}
This paper presents the findings of a survey among 18 central banks from the Asia-Pacific region regarding their views on, and policies regarding, sustainable finance. It also reviews recent developments in selected Asia-Pacific countries regarding sustainable finance to illustrate actions monetary and financial authorities have already taken to address climate and environmental risk, and in scaling up sustainable finance. The survey results show that this is a topic of increasing importance and relevance to monetary authorities in the region, many of whose countries are impacted particularly hard by the effects of climate change. The vast majority of survey respondents believe that they should be playing a key role in promoting green finance and sustainable funding options, either through amending the regulatory framework, encouraging green loans and products or by introducing climate change considerations in their monetary and financial policy operations. A number of central banks and supervisory authorities are already promoting sustainable financing options explicitly or implicitly. Whilst most respondents did not feel that current regulatory frameworks implicitly support high-carbon industries, several are putting in place beneficial capital provisions or regulatory frameworks to encourage banks to scale up lending to low-carbon industries. The majority of respondents have not developed capacity building or training programmes for their staff or the external financial community as yet, although a number of initiatives are underway.
\end{abstract}

Keywords: Sustainable finance; central banking and financial supervision; Asia-Pacific.

* The views expressed in this paper are those of the authors alone and do not necessarily reflect the views of SEACEN or its member institutions. The authors are grateful for useful comments received from participants at the SEACEN High-Level Seminar and Meeting for Deputy Governors of Financial Stability and Supervision in Kuala Lumpur in July 2019, a Distinguished Speaker Seminar at the Asian Development Bank Institute (ADBI) in Tokyo in August 2019, the National Asset-Liability Management Asia Conference in Singapore in September 2019, and an ADBI workshop on "Green Infrastructure Development in Asia: Investment, Financing and Economic Impacts" in November 2019. The usual disclaimer applies. 


\section{Introduction}

Climate change has become a hot topic for financial markets. An understanding is gradually emerging that central banks and financial supervisors ought to address climate risks and support sustainable finance (Batten et al., 2016; Volz, 2017; Campiglio et al., 2018; Dikau and Volz, 2019a). This is best exemplified by the establishment and rapid growth of the Central Banks and Financial Supervisors Network for Greening the Financial System (NGFS), as well as the Sustainable Banking Network (SBN). The NGFS was established in 2017 by eight central banks and supervisory authorities and has grown to 54 members and 12 observers by December 2019. ${ }^{1}$ The NGFS members have reached a firm consensus that climate change constitutes a source of financial risk that ought to be addressed by central banks and financial supervisors (NGFS, 2019). Established in 2012, the SBN is an informal group of 53 financial regulators and banking associations that seek to develop sustainable banking policies, guidelines and practices. Moreover, a growing number of central banks and supervisors - 36 as of June 2019 - has committed to support climate-related financial disclosures reporting following the recommendations of the Task Force on Climate-related Financial Disclosures (TCFD) (TCFD, 2017; TCFD, 2019). ${ }^{2}$ A discussion is also emerging about what role - if any central banks should be playing in scaling up sustainable finance to facilitate achieving the Sustainable Development Goals (SDGs) and the Paris Agreement.

Sustainable finance has also become a focal topic across the Asia-Pacific region, with a growing number of monetary and financial authorities starting to consider how to incorporate climate and other environmental considerations into their policy frameworks or encourage financial institutions to incorporate environmental, social and governance (ESG) standards in lending and investment and adopt environmental and social risk management (ESRM) practices (Volz, 2019). Still, for most monetary authorities - in the Asia-Pacific region but also elsewhere climate risk and sustainable finance are new areas in which they have little expertise.

Against this backdrop, this paper seeks to take stock of the views and emerging policies of central banks from the Asia-Pacific region in the area of sustainable finance. To this end, we conducted a survey among 18 central banks and monetary authorities in the Asia-Pacific region to find out more about their attitudes regarding climate change and sustainable finance. ${ }^{3}$ The survey was sent to member institutions, associate members and observers of the South East Asian Central Banks (SEACEN) Research and Training Centre in the second quarter of 2019.4 The key findings of the survey are as follows: A number of Asia-Pacific central banks and regulatory authorities are already explicitly or implicitly promoting sustainable financing. The vast majority believe that they should be playing a key role in promoting sustainable finance, whether through providing capacity building, setting the regulatory framework, encouraging green loans and products and introducing climate change considerations in their monetary and financial policy frameworks. Whilst most respondents did not feel that the Basel framework implicitly supports high-carbon industries, a number are putting in place beneficial capital and

\footnotetext{
${ }^{1}$ Observers include the International Monetary Fund, the World Bank, the Bank for International Settlements, the Basel Committee on Banking Supervision and the Organisation for Economic Cooperation and Development, among others.

2 The TCFD was established by the Financial Stability Board in January 2016 and chaired by Michael Bloomberg.

${ }^{3}$ There is no single agreed definition of the countries comprising the Asia-Pacific region. We follow the widely used convention that it includes countries from Northeast, Southeast and South Asia as well as Oceania.

${ }^{4}$ The SEACEN Centre was established as a legal entity in 1982 with a membership of eight central banks / monetary authorities. It has since grown to 19 members, and a total of 35 including associate members and observers.
} 
regulatory frameworks to encourage banks to lend to low-carbon industries. The majority of respondents have not put in place any capacity building or training programmes for their staff or the external financial community as yet, although several initiatives are underway.

The paper also reviews recent developments in selected Asia-Pacific countries regarding sustainable finance to illustrate actions monetary and financial authorities have already taken to address climate- and environment-related financial risks, and to scale up sustainable finance. The examples of six Asia-Pacific countries - Bangladesh, the People's Republic of China (PRC), India, Indonesia, Singapore and Viet Nam - clearly show that central banks and monetary authorities are increasing their efforts to address climate risks and align the financial system with sustainability goals. At the same time, these examples also show that policy frameworks are still evolving and much remains to be done to develop comprehensive responses.

The remainder of the paper is structured as follows. Section 2 briefly discusses why central banks and financial supervisors should care about climate change and environmental sustainability. Section 3 presents the findings of the survey discussed above. Subsequently, Section 4 reviews the steps taken by central banks and monetary authorities in six Asia-Pacific countries to scale up sustainable finance. Section 5 concludes with a discussion of policy options central banks and supervisors across the Asia-Pacific region should consider.

\section{Why should central banks and financial supervisors care about climate change and environmental sustainability?}

Whilst some have argued that climate change should be solely dealt with by governments, and lies outside the mandate of central banks, climate change brings with it two main effects that directly impact the financial system and hence make it a prudential risk that ought to be dealt with by financial regulators. Firstly, there are the physical effects of polluting carbon intensive industries and forest burning. The associated rise in global temperatures contributes to shifting weather patterns and more frequent occurrences of typhoons, heatwaves, floods, hurricanes and storms. The illnesses, displacement, destruction and death arising from such events, along with the disruption of manufacturing capabilities, supply chains and trade flows, have an effect on short and long-term growth as well as financial stability. Furthermore, financial firms that have insured or lent to corporations or households affected by such events are likely to experience higher levels of claims and losses in those portfolios if they don't account for these risks. Central banks and supervisors therefore ought to consider the physical risk and impacts that climate change will have upon the institutions they supervise, as well as the wider financial system.

Secondly, in addition to such physical effects, there are transition risks as societies move towards low-carbon alternatives. Industries that heavily depend on fossil fuels face greater scrutiny and regulatory burden. For instance, France and the UK plan to phase out the sale of all diesel and petrol vehicles by 2040, while the Netherlands requires all office buildings to meet certain energy standards by 2023. Credit ratings and share prices for coal companies have already fallen considerably, and oil, gas and car companies that do not adapt in time could face similar outcomes, with impacts on suppliers and employment in these sectors, which in turn would affect the wider financial system. Again, those institutions that are lending against and insuring the affected organisations will potentially see higher levels of claims, as well as lower collateral values and greater non-performing loans and losses arising from such 
exposures. They will need to revise their lending policies and procedures to account for these risks or otherwise suffer financial losses and reputational damage. The NGFS (2019) acknowledged that climate change poses a serious threat to financial stability and has issued a "call for action" for central banks and supervisors to develop their microprudential and macroprudential tools to address both physical and transition risks.

Thirdly, it has been recognised that climate change may have direct consequences for price stability. First, there is a potential impact on food and energy prices or employment in crucial sectors such as agriculture and natural resources extraction (Volz, 2017). Furthermore, climate change can lead to supply-side shocks that could cause a trade-off for central banks between stabilising output fluctuations and inflation (Cœuré, 2018). Finally, different climate policy regimes - such as the introduction of carbon taxes or permit trading systems - could affect different monetary policy regimes (McKibbin et al., 2017).

A review of central bank mandates conducted by Dikau and Volz (2019b) analyses the extent to which climate-related financial risk and mitigation policies align with the current set of central bank mandates and objectives. Using the IMF's Central Bank Legislation Database, they analysed the mandates of 133 central banks. Of these, only $12 \%$ have mandates that explicitly refer to sustainability goals; however, a further 29\% are mandated to support the government's policy priorities, which should usually include sustainability goals such as the Paris Agreement and the SDGs. Given that climate risks can directly affect monetary and financial stability - the traditional core responsibilities of central banks -, Dikau and Volz argue that also central banks that have no explicit or implicit sustainability objectives in their mandate should incorporate climate-related physical and transition risks into their core policy implementation frameworks to ensure that they safeguard financial and macroeconomic stability.

Thus, whilst some have argued that climate change is outside the mandate of central banks and supervisory authorities, given that the effects of climate change directly impact the financial system, there is now ample evidence that it should be deemed a material risk to financial stability and hence an area of supervisory and central banking policy focus. As such, there are a number of policy options open to central banks and supervisory authorities. The decision on what actions to take and how far to go down the path of encouraging low carbon financing will need to be considered carefully by each authority.

\section{Findings of a survey among 18 central banks and regulatory authorities from the Asia-Pacific region regarding their views on and policies regarding sustainable finance}

In light of the increasing importance of climate change and the debate around what role, if any, central banks and regulators should play in promoting low-carbon or green finance, the SEACEN Centre surveyed its membership on their views, opinions and recommendations. The SEACEN Centre was founded in 1982, with a membership of originally eight central banks and monetary authorities, namely Bank Indonesia, Bank Negara Malaysia, Central Bank of Myanmar, Nepal Rastra Bank, Bangko Sentral ng Pilipinas, Monetary Authority of Singapore, Central Bank of Sri Lanka, and Bank of Thailand. Since its inception, its membership has grown to 19 members, with the addition of the Bank of Korea, Central Bank Chinese Taipei, Bank of Mongolia, Autoriti Monetari Brunei Darussalam, Bank of Papua New Guinea, National Bank of Cambodia, State Bank of Vietnam, People's Bank of China, Bank of the Lao PDR, Reserve Bank of India and Hong Kong Monetary of Authority. In addition to its 19 members, SEACEN has 16 
other associate members and observers. The associate members are Reserve Bank of Australia, Bangladesh Bank, Royal Monetary Authority of Bhutan, Monetary Authority of Macau, State Bank of Pakistan, National Reserve Bank of Tonga, Reserve Bank of Fiji and Reserve Bank of Vanuatu. The observers are Da Afghanistan Bank, Central Bank of the Islamic Republic of Iran, Bank of Japan, Maldives Monetary Authority, Reserve Bank of New Zealand, Central Bank of Samoa, Central Bank of Solomon Islands and Central Bank of Timor-Leste.

The survey was designed to gain insights on the views, key issues and opportunities that central banks and monetary authorities across Asia-Pacific face when considering climate risk and the low-carbon transition, as represented in the Paris Agreement. 13 questions on low-carbon and green financing were formulated and sent for completion by the institutions. Respondents were also provided the opportunity to provide qualitative responses.

Out of SEACEN's 35 members, associate members and observers, a total of 18 central banks/monetary authorities responded to the survey (14 member and 4 associate/observers). For the sake of convenience, we will in the following refer to responding institutions as central banks, even though the sample includes also monetary authorities. The survey was undertaken in the second quarter of 2019. The survey was initially sent to the SEACEN Liaison Officer at each institution, who then forwarded it to the key decision makers overseeing the areas of climate risk and sustainable finance. The collective responses and views have been anonymised and are presented below. Figures 1-4 provide an overview of the survey responses and are also discussed below.

A clear majority of the responding central banks - 16 out of 18 or $89 \%$ - agree that low-carbon finance has become an important area of focus, particularly after the ratification of the Paris Agreement (Figure 1, Q.1). A third of the responding institutions have already issued policy statements on climate change and green finance (Figure 1, Q.2). In the open remarks to Q.2, one central bank stated that it is currently drafting a Sustainable Finance Policy Framework to guide banks in embedding ESG/ESRM principles in their business decisions, and to facilitate the flow of capital to green industries and activities in a risk-based, market oriented and sustainable manner. Three central banks stated that they have already issued guidelines or regulations on ESRM and sustainable lending. Another two central banks referred to policy speeches in which their respective governors emphasised that both physical and transition impacts of climate change are likely to have first-order economic effects in the country and that environmental and ecological risks are key challenges for the banking sector. Both governors highlighted that awareness of the various sustainability challenges is essential for the financial sector.

[Figure 1 about here]

Almost all responding central banks (94\%) think that they should play a role to help encourage low-carbon financing initiatives and green finance such as green bonds (Figure 1, Q.3). This question generated numerous comments, some of which are presented in Box 1. 


\section{Box 1: Selected open responses to Q.3 - "In your opinion, should your institution be involved in playing a role to help encourage low-carbon financing initiatives / green finance (e.g. green bonds)?"}

- As a regulator of the banking system, we advocate and encourage banks to practice sustainable finance, which also encompasses green/climate finance. Through our membership in the SBN, we started the journey to fully understand the landscape within and outside the country to better identify and implement strategic actions that mainstream sustainable finance in the banking sector. We have conducted studies, knowledge exchanges, forums, roundtable and focus group discussions with banks and other key stakeholders to raise greater awareness and encourage adoption of environmental, social and governance (ESG) principles and Environmental and Social Risk Management (ESRM) tools in banking operations. We have also conducted several ESG/ESRM trainings for senior management and risk officers of selected banks, in response to their expressed need for capacity building. These initiatives aimed to signal the market about the importance of sustainability objectives.

- $\quad$ There may be a role for the central bank, where impediments or data gaps are identified.

- Financial regulators should play a stewardship role and be a key driver for encouraging low-carbon financing initiatives, and comprehensively uphold relevant stakeholders such as commercial banks, to actively partake in any form of green financing.

- We believe that central banks and regulators have a large role to play in influencing the outcome of environmental and climate change. This is because environmental and climate change may significantly impact the economy and generate financial risks, primarily through two channels - physical and transition risks. These risks will impact macroeconomic conditions on the demand and supply side which can potentially result in large financial losses and instability in food and energy prices. The financial risks are system-wide and potentially irreversible if not addressed, thus posing a threat to central banks' policy mandate in achieving financial stability.

- Central banks play an important role in ensuring that the financial system is resilient to these risks. Central banks also have a role in scaling up green finance as part of their efforts to advance the sustainability agenda. In our country, the central bank is supportive of sustainability as a national agenda and believes that finance plays an important role in achieving the 2030 SDGs.

- The following areas can be pursued by central banks to encourage green finance initiatives: (i) Incorporating environmental and climate change considerations in monetary policy and financial stability mandates, as well as in its own operations and practices. (ii) Undertaking studies on the impact of environmental and climate change risks on the domestic economy and players including financial system. (iii) Promoting close collaboration and cooperation among central banks, regulators and other government/multilateral agencies to ensure that the physical and transition risks arising from environmental and climate change are well managed.

- Being the central bank and financial regulator, it is our duty to take policy initiatives on low carbon financing through banks and financial institutions.

- At some degree, the central bank might be involved with this issue, concerning the following issues: (i) Processing industry (mainly raw material) and agriculture industry are the largest supporter of our GDP. Therefore, the existence of natural and sustainable resources needs to be protected. (ii) The central bank acts as the country's investor relation unit. Therefore, we might support investors to identify green economy activities that contribute significant impacts to the economy and need to be funded.

- As the regulator of [the] financial system, it is important that the central bank initiates change and shows examples for the industry to follow.

Source: SEACEN Survey, 2019: Q2.

Seven of the responding institutions or $39 \%$ have already established special task forces, divisions or groups within their institutions that focus on climate actions and mainstreaming green finance (Figure 1, Q.4). Of those who have already set up teams to deal with climate and sustainability issues, four institutions located them in their banking supervision unit, four in the policy unit, three in a financial inclusion unit, two in a risk specialist unit, one in a corporate social responsibility / environmental unit, and a further four in other units (Figure 2, Q.5). The 
"other" units were housed in the research and statistics department; the financial inclusion and development division; the economics, financial stability, investment operations unit; and in a dedicated department on climate actions and mainstreaming green finance titled 'Sustainable Finance Department.'

[Figure 2 about here]

$22 \%$ of the survey respondents stated that their institution currently has a strategic investment mandate or approach to scale up private investment in low carbon- sectors (Figure 3, Q.6). One central bank commented that it had devised a specific target to scale up private investment in low carbon-sectors in the central bank's strategic plan, while two other central banks reported on directed lending policies they had already implemented in the banking sector to scale up renewable energy lending. 13 central banks (72\%) are aware of national commitments or contributions set-up in their country to help implement green finance and low carbon financing initiatives (Figure 3, Q.7). There are a number of national policies and commitments across the region that have been set up to help the implementation of green finance. These include national green growth strategies or frameworks that support ESG investments; government guarantee schemes for lending directed towards green technology investments, including renewable energy; public support schemes for clean energy investments; green finance roadmaps or action plans; a Sustainable Development Financing Fund that seeks to incentivise companies to adopt sustainable practices in their business strategies and operations; a Peoples Survival Fund to finance investment in disaster resilience, climate mitigation and adaptation; and a Sustainable and Responsible Investment Sukuk Framework, among others.

[Figure 3 about here]

Only $18 \%$ of responding central banks think that capital lending for low-carbon investment has been constrained by the implementation of international banking regulatory frameworks such as Basel II and III (Figure 3, Q.8). However, around a third of the responding institutions have issued financing instruments or implemented regulatory policies or initiatives that aim to encourage private financing for low-carbon investments, or related green savings instruments (or discourage carbon-intensive industries), including 'green supporting' or 'brown penalising' factors to enhance the Basel regulatory framework (Figure 3, Q.9). Open responses are shown in Box 2.

Box 2: Selected open responses to Q.9 - Has your institution issued any financing instruments or implemented regulatory policies or initiatives that aim to encourage private financing for low carbon investments, or any related green savings instruments?

- We implemented advocacy and capacity building initiatives. We are also in the process of implementing regulatory policies.

- We do not have regulatory policies aiming to encourage low-carbon financing, but we do have a plan toward sustainable finance. 
- Financial institutions are encouraged to undertake an intermediation function that delivers the intended outcomes of Shariah through practices, conduct and offerings that generate positive and sustainable impact to the economy, community and environment, consistent with the shareholders' sustainable returns and long-term interests.

- $\quad$ There are policies on Green Finance and refinancing schemes on Green Finance.

- $\quad$ Since 2013, the Central Bank already prescribed regulations for banks to engage with green economy financing. Therefore, banks that support such financing to the green economy [may benefit from] lower credit risk, legal risk, and reputational risk, compared to those who did not participate.

- $\quad$ Directed lending policy for banks to lend towards renewable energy projects.

- In order to scale up private investment in low carbon-sectors, the regulator conducts several activities, including: (1) encouraging banks and insurance companies to incorporate environmental issues into their investment and financing decisions; (2) assisting the green energy industry to obtain financing; (3) channelling investments into the green energy industry; and (4) facilitating responsible investments to the capital markets.

- To encourage private financing for low carbon investments, one of the key measures in the Green Finance Action Plan is that when calculating the capital requirement for claims on green corporations that benefit from credit protection given by Official OECD Export Credit Agencies, banks are allowed to apply a risk weight one category less favourable than that assigned to the sovereign rating of the guarantor's country of incorporation.

Source: SEACEN Survey, 2019: Q2.

None of the responding central banks is aware of plans to set up a green bank under their supervisory control (Figure 4, Q.10). Most respondents (78\%) hold the view that increased regional co-operation and policy co-ordination in the real and financial sectors will promote low carbon investment (Figure 4, Q.11). 13 out of 14 respondents consider a regional finance warranty programme as "most significant" or "significant", and the same goes for 12 out of 14 for a regional fund for financing low-carbon projects. Only 8 out of 13 consider a regional carbon tax as "most significant" or "significant", while 10 out of 14 consider a regional green bond market a good or very good idea. In the open comments, several central banks suggested that a taxonomy -i.e., a common definition on low carbon financing/investment - will facilitate greater investment and standardised data collection for analysis.

[Figure 4 about here]

With respect to the education of the wider public on issues relating to ESG, only 4 out of the 18 responding institutions (22\%) have implemented awareness programs to improve savers and investors' understanding of climate change related challenges and opportunities (Figure 4, Q.12). But 7 institutions (39\%) have already started to set up capacity building programs to train internal staff and also external financial services personnel to understand climate change challenges and opportunities (Figure 4, Q.13). Of these, most have organised, or are doing so at the moment, internal trainings or seminars/workshops. Some have organised capacity building workshops, stakeholder dialogues or consultation events with financial institutions. Some have invited relevant experts from multilateral financial institutions. 


\section{What are central banks and monetary authorities across the Asia-Pacific region doing?}

The survey finding show very clearly that central banks and monetary authorities across the Asia-Pacific region have grasped the importance of addressing climate-related risks and see the promotion of sustainable finance as a responsibility they need to address. Indeed, we gradually see central banks across the Asia-Pacific region starting to address the sustainability challenge. In the following, we provide examples of actions that are already being taken by central banks and monetary authorities in six Asia-Pacific countries: Bangladesh, the PRC, India, Indonesia, Singapore and Viet Nam. ${ }^{5}$

\section{Bangladesh}

Bangladesh Bank, the central bank of Bangladesh, was among the very first central banks globally to address environmental challenges. In 2011, Bangladesh Bank issued an Environmental Risk Management (ERM) directive which mandated banks to incorporate ERM policies into their credit risk management. Later in the same year, Bangladesh Bank issued policy guidelines for green banking. The policy guidelines were adopted gradually in three phases, in order to facilitate a smooth transition in greening the banking system. The first phase introduced policy formulation and governance, the incorporation of environmental risk in core risk management, the initiation of in-house environmental management, the introduction of green finance, green marketing initiatives, and the launch of a climate risk fund. In the second phase, additional initiatives were put in place such as integrating sector specific environmental policies, green strategic planning, creation of green bank branches, as well as the disclosure and reporting of green banking activities. In the final phase, a standard reporting template that required banks to detail their green banking activities was introduced. In 2013, the green banking guidelines were extended to non-bank financial institutions, bringing the financial sector under one uniform reporting system.

Bangladesh Bank also issued several directives to banks and financial institutions. In order to boost green finance in Bangladesh, banks were instructed to provide financial assistance to green projects, with a minimum of five percent of their total loan disbursement or investment. In addition, banks and financial institutions were mandated to set up a climate risk fund. Ten percent of banks' and financial institutions' corporate social responsibility budget has to be allocated to the climate risk fund. The funding can be undertaken through either the provision of grants or through financing at lower interest rates. Starting from December 2016, banks and financial institutions were instructed to establish sustainable finance units.

Banks and financial institutions have also been required to green their infrastructure, for example through utilising solid-waste management, rain-water harvesting and the installation of solar rooftop panels. Bangladesh Bank also prepares a quarterly report on green banking activities in the country to monitor the fulfilment of such initiatives. Bangladesh Bank has also worked to reduce its own in-house carbon footprint by installing solar rooftop panels, centralized air-conditioning systems and installing motion sensor lighting systems in its buildings to reduce electricity usage.

Furthermore, the Bank has launched a number of refinancing schemes to provide various lowcost financing facilities for green projects. A refinancing scheme of two billion taka (US\$ 23.7 million) was established to fund green projects in 2009. In 2012, Bangladesh Bank, with the

\footnotetext{
${ }^{5}$ For a more comprehensive review of sustainable finance across Asia, see Volz (2019).
} 
assistance of the Asian Development Bank, established an on-lending scheme known as the "Financing Brick Kiln Efficiency Improvement Project", which aimed to reduce greenhouse gas emissions and refine particulate pollution from brick fields. It also established a refinance scheme funded by excess liquidity of shariah banks to promote the involvement of shariah banks and financial institutions in green finance. In January 2016, Bangladesh Bank placed a longer-term refinancing scheme of US\$200 million known as the Green Transformation Fund, which was set up to support the export-oriented textile and leather sectors, in line with the green transformation of the economy.

In 2017, Bangladesh Bank enhanced its guidelines on ERM, by issuing new Guidelines on Environmental and Social Risk Management. These incorporated social measures and additional parameters into their previous standards, and were supported by technical assistance from the International Finance Corporation. A new reporting format of green banking activities was also put in place in 2018 to ensure the quality and consistency of data moving forward.

\section{People's Republic of China}

The PRC has emerged as one of the leading countries in the world when it comes to encouraging the green and low carbon financial sector. The level of pollution across the country has been severe, affecting the availability of clean water, air and arable land, and resulting in illness and lowering life expectancy. This has been caused by the rapid (and highly polluting) industrial development across the country, centred around manufacturing and heavy industry, and supported by equally polluting energy and transportation structures. Environmental pollution and its effects have been leading to a loss of GDP and wellbeing. This has forced the government and its institutions to act, in order to try and reflect the negative externalities of the polluting industries into the costs they face, and ultimately the prices they charge for their products.

Led by the country's government and regulatory agencies, a combination of policies and institutional arrangements have been developed to facilitate the provision of loans, bonds, equity, insurance products and private funds to the green industry (i.e. those focused on low carbon-intensive products and solutions). Green finance was included in the report of the 19th National Congress of the Communist Party of China, and the standardisation of green finance was set as one of the key tasks for the financial services industry in the 13th Five-Year plan, which covers the period 2016-2020. The four key areas that are subject to increased green development are: industrial development; energy structures; transportation; and agricultural infrastructures.

The initial challenge the PRC faces, along with all other countries that wish to promote green finance, is that the current market system does not adequately price in the cost of externalities into the market prices for goods. Arguably, the current Basel regulatory framework further compounds this issue, by inadvertently penalising many green finance projects through higher risk weights (since they tend to have longer tenors, with less political and policy certainty over the project horizon, for example), whilst brown finance projects tend to attract lower risk weights. One of the key areas of focus for the government policy and the People's Bank of China (PBOC) have been to reverse some of these incentives, through increasing the return on green finance projects, reducing the returns on brown finance projects and encouraging the level of transparency in the market so consumers can also make informed choices. 
To mobilize green finance, the PRC has implemented mandatory disclosures for banks, to categorise what is 'green' lending, 'brown' lending and 'neutral' in their portfolios. Banks are able to earn green 'points' that contribute to the PBOC's risk assessments. Risk weights can be lowered for 'green' assets based on empirical evidence of lower risk, e.g. lower non-performing loan ratios for green loans.

The PBOC is also targeting monetary and regulatory policy tools to further incentivise green lending. Green bonds and loans already form part of the macro-prudential assessments carried out by the PBOC, which has expanded its Medium-Term Lending Facility to incorporate such products. Green Finance Pilot Zones have been established and banks in these zones have been increasing their level of green lending. All this will also mean that there will be opportunities for green asset securitisations or green covered bond programmes further down the line. This would then help recycle some of the capital within these products to further expand the green finance market. The PBOC has also launched a green refinancing policy which allows commercial banks to use green loans/bonds as collateral for borrowing from the PBOC at discounted rates, funds from which then have to be on-lent to green businesses.

To further help standardise the definition of 'green', the PBOC and the China Securities Regulatory Commission (CSRC) jointly issued guidelines for green bond verifiers and verification activities in the PRC. This is essentially a verifier licencing scheme, outlining tighter controls and higher penalties to ensure the products are genuinely green. They stipulate certain required qualifications and credentials, verification methods, and reporting requirements. The scheme is broadly modelled on the international Climate Bonds Standard and Certification Scheme. Before they can undertake green bond reviews, verifiers will have to register with the Green Bonds Standard Committee and provide evidence of: (i) professional expertise in assurance, accounting and auditing; (ii) expertise in key qualifying sectors, such as clean energy and low-emission transport; (iii) having current professional liability insurance cover; and (iv) having established internal procedures, pricing structures and quality control. Verifiers will also be required to undertake ongoing training to remain competent. The Green Bonds Standard Committee will be reviewing the practices of verifiers and sharing of the results through designated websites. The Guidelines also require verifiers to ensure their independence: no economic interests or affiliations between verifiers and issuers are allowed.

In 2017, the CSRC also issued its "Guidelines for the Disclosure of Contents and Formats of Listed Companies." This required firms listed as major polluters to disclose a variety of environmental information, with others encouraged to disclose on a 'comply or explain' basis. This was followed by the PBOC issuing circulars on "Strengthening the Supervision and Administration of the Duration of Green Bonds" and "Disclosure Requirements on Green Bonds." These require quarterly disclosure of green benefits as well as details on violations of environmental standards.

As a result of all these policy actions, the PRC is now one of the world's largest green bond issuers. The first green bond by a Chinese bank was issued in 2015 by the Agricultural Bank of China, and the first covered green bond by Bank of China in 2016. Green issuances in 2018 included Industrial and Commercial Bank of China (ICBC), the world's largest bank, with US 1.58 billion and Bank of China with US\$ 1 billion - both issued on the London market. The Climate Bonds Initiative and the China Green Finance Committee have forecast that the Green Bond market will grow to US\$ 1 trillion annually by the early 2020's, and the PRC's share of this would approximately amount to $40 \%$. Clearly there are still issues around ensuring what is genuinely 
'green' and whether, for example, 'clean coal' would fit into this, but the PRC is certainly trying to strengthen its green finance market.

Further support on green financing comes from the development of the PRC's green private equity investment market. There are now over 500 green private equity funds according to the China Securities Investment Fund Association (178 green funds were setup in 2018). These firms can then invest in a variety of clean-tech and green focused companies, which may otherwise struggle to raise funds. A green stock index system has also been implemented, along with a green insurance system. It has been made compulsory to hold environmental pollution liability insurance, and in 2017 such insurance amounted to RMB 30.6 billion (US\$ 4.6 billion) across 16,000 firms.

To promote the idea of green finance globally, the PRC's G20 Presidency initiated the Green Finance Study Group in January 2016, co-chaired by the PBOC and the BoE. This was later renamed the G20 Green Finance Study Group, and it was instrumental in making green/sustainable finance an issue for all finance ministries and central banks of the G20 countries. The PBOC was also one of the eight founding members of the NGFS, which was launched in December 2017 after the climate topics became a difficult topic in the G20 format.

In response to international criticism, the PRC has also started to green the Belt and Road Initiative (BRI), President Xi Jinping's international flagship strategy aimed at fostering infrastructure development in more than 65 countries along the Silk Road Economic Belt and the 21st Century Maritime Silk Road. In 2016, President Xi Jinping called for the "greening" of the BRI. Both the China Development Bank and ICBC have since issued "Green Belt and Road Bonds", which were certified by the Climate Bonds Standard.

\section{India}

India is the world's fourth largest carbon emitter. It ratified the Paris Agreement in 2016 and as such needs to reduce its carbon emissions by 30-35\% (from its 2005 levels) over the next 12 years. The Reserve Bank of India (RBI) published a notice to banks - 'Corporate Social Responsibility, Sustainable Development and Non-Financial Reporting - Role of Banks' - as far back as December 2007. This was followed up with a letter sent out in October 2011, to all non-banking financial corporations, entitled 'Implementation of Green Creativity of the Government.' The letter requested organisations to take steps to improve their use of resources and provide for better delivery of amenities.

A core of the financial policy in India has been the so-called Priority Sector Lending (PSL) requirement, which stipulates that banks should allocate $40 \%$ of their lending to areas deemed socially important, including agriculture and small and medium-sized enterprises. In 2015, the $\mathrm{RBI}$ added lending to social infrastructure and small renewable energy projects to the target sectors, supporting green financing. In the renewable energy segment, bank loans for solarbased power generators, biomass-based power generators, windmills, micro-hydel plants and others can all be considered part of PSL requirements. In addition, India's External Commercial Borrowing regulations have been liberalised so that green projects can utilise such facilities for raising finance from overseas lenders.

A green bond market emerged in 2015, with a total volume of US\$ 1.1 billion of green bonds issuances by Yes Bank, Export-Import Bank of India, CLP Wind Farms and IDBI. In August 2015, the first green Masala bond (rupee denominated green bonds offered on overseas exchanges) 
was floated by the International Finance Corporation (IFC) on the London Stock Exchange, raising INR 3.15 billion. At the beginning of 2016, the Securities and Exchange Board of India (SEBI) launched a framework for the issuance of green bonds and their listing requirements. ${ }^{6}$ In May 2017, SEBI laid the disclosure guidelines that would govern the issuance and listing of green bonds in India. The guidelines define green bonds in a wider context, require bond issuers to provide disclosure in offer documents, and to report on the use of proceeds and unutilised proceeds along with their half yearly and annual financial results. In 2018, the State Bank of India, India's largest public-sector bank, issued its first green bond raising US\$ 650 million, with orders amounting to over US\$1.25 billion.

Moreover, the Parliament of India enacted the Companies Act in 2013 which directs big companies to contribute a minimum $2 \%$ of their average net profits towards Corporate Social Responsibilities activities that promote proper health care and sanitation, reduce poverty and safeguard environmental sustainability. In order to encourage the enterprises to shift to greener production, the Government created specialised funds such as the Textile Upgradation Fund, the Credit Linked Capital Subsidy Scheme and the Tannery Modernisation Scheme. It also launched a 'National Clean Energy Fund' to support research and innovative projects in clean energy technologies. The Fund is financed by a tax of INR 200 per tonne on coal mined in India or imported into India. India is also proposing to set up a green bank to fund clean energy projects. Such a bank would accept public deposits and then fund clean energy projects at reduced interest rates.

\section{Indonesia}

Indonesia has sought to establish itself as a leading player in the green finance market. ${ }^{7}$ Bank Indonesia, the country's central bank, was initially a key player in promoting green finance, ${ }^{8}$ but after the establishment of Indonesia's Financial Service Authority (OJK) in 2011, Bank Indonesia's green finance team moved to OJK in 2013, which then took the lead on this topic. In 2014, OJK produced a Sustainable Finance Roadmap, which laid out a comprehensive plan for promoting sustainable finance. The roadmap covered both the medium-term (2015-2019) and the longer-term (2015-2024) plan for the financial services industry. The aim of the roadmap was to promote sustainable development through key government, industry and international institutions. Given the high level of demand for energy to continue supporting Indonesia's development, the sustainable finance programme set out to promote energy conservation, as well as the funding of new and renewable energy sources. Other areas of focus include agriculture, processing industries, general infrastructure and micro, small and medium and enterprises.

Since July 2017, OJK requires banks to develop action plans for sustainable financing and to report their green financing exposures. This further helped the development of the green finance sector and shed light on which banks are financing carbon-heavy industries and to what extent. Further support from the OJK came with the launching of the Bali Centre for Sustainable

\footnotetext{
6 In 2012, SEBI created requirements known as the Annual Business Responsibility Reporting, a reporting framework based on the National Voluntary guidelines on Social, Environmental and Economic Responsibilities of Business (NVGs) that had previously been released by the Ministry of Corporate Affairs. Such reporting requirements also subsequently increase demand for sustainability-linked financing.

${ }^{7}$ On the emergence of sustainable finance in Indonesia see Volz (2015) and Volz et al. (2015).

8 In 2012, Bank Indonesia issued Green Lending Model Guidelines for Mini Hydro Power Plant Projects.
} 
Finance, which was jointly undertaken with Udayana University in 2017. The aim of the centre is to build capacity and learning networks for sustainable finance.

In 2018, Indonesia was the first country globally to issue a green sovereign Sukuk bond. The deal was massively oversubscribed so that the volume was increased while the pricing was lower than expected. The proceeds raised from the placement were directed towards a number of eligible projects including investments in renewable energy, public transport, lowcarbon buildings, and water and waste management. The Government of Indonesia has sought to streamline existing regulations to relax administrative requirements and facilitate the financing of infrastructure projects by provincial governments, which is expected to propel the development of a municipal green bond market.

In November 2019, Bank Indonesia joined the NGFS. In the NGFS, Bank Indonesia will contribute to workstream 2 on "Macrofinancial" and workstream 3 on "Scaling Up Green Finance". It also announced a sustainable finance task force to coordinate efforts in strengthening the role of Bank Indonesia in helping Indonesia to achieve the SDG targets.

In order to support the further growth of the country's infrastructure provision in this environmentally sustainable manner, the Government of Indonesia has taken a number of steps to promote green infrastructure financing. It has made improvements to the public private partnership (PPP) regulations for infrastructure, developed a scheme for providing subsidies and credit enhancement for PPPs, and established an Indonesian Internal Credit Rating scorecard system as well as the Indonesia Infrastructure Guarantee Fund to manage sovereign guarantees. Furthermore, there is additional support for blended finance, combining commercial and development organisation finance to mobilise additional finance towards sustainable development, which also supports the OJK's sustainable development roadmap.

\section{Singapore}

The Monetary Authority of Singapore (MAS) was another of the founding members of the NGFS. The MAS is also a member of the Sustainable Insurance Forum, a global network of 25 insurance supervisors and regulators aiming to enhance sustainability practices in the insurance industry. The MAS has also implemented a number of schemes to promote sustainable financing in Singapore. One such initiative is the creation of the Asia Sustainable Finance Initiative, a multi-stakeholder forum that aims to utilise the power of the financial sector to deliver on the SDGs and the Paris Agreement, in January 2019. The forum convenes stakeholders from the financial sector, academia and NGOs to support financial institutions in implementing ESG best practices. As Singapore is a conduit for financial flows into Asia, it is hoped that the lending and investment decisions taken by financial institutions based there will have a significant impact on the region's contribution to a 1.5-degree world and its climate resilience.

In March 2017, the MAS launched a Green Bond Grant scheme to encourage the issuance of green bonds in Singapore. The scheme allows qualifying issuers to reimburse hundred percent of the additional costs of obtaining an external review of a green bond, up to $\$ \$ 100,000$ per issuance, thereby lowering the hurdle for green bond issuers to enter the market. The scheme runs until 31 May 2023. To be eligible for a grant, the bonds must meet three requirements regarding qualifying issuers, eligible expenses, and qualifying criteria. The eligible expenses for the green bond grant scheme require the appointment of an external reviewer in order to 
obtain an independent assessment of the proposed bond, based on internationally recognised standards, such as the International Capital Market Association's Green Bond Principles, Climate Bond Initiative's Climate Bond Standard or the Association of Southeast Asian Nations (ASEAN) Green Bond Standards that were developed by the ASEAN Capital Market Forum.

In addition to this, in 2018 the MAS signed a memorandum of understanding with the IFC, to work together to accelerate the growth of the green bond markets in Asia. Under this agreement, IFC and MAS will set out to encourage green bond issuances by financial institutions in Asia through enhancing the awareness and knowledge of professionals working in financial institutions on green finance issues. They will also promote the use of internationally recognized green bond standards and frameworks.

In 2018, the Association for Banks in Singapore issued Guidelines on Responsible Financing with the support of the MAS. These define the minimum standards on responsible financing practices to be integrated into members' business models. The Responsible Financing Guidelines build on values such as governance, transparency and trust, in order to support more transparent ESG disclosures. Moreover, the Singapore Exchange has required all listed companies to report on sustainability, on a "comply or explain" basis, from 31 December 2017. The MAS also supported the development of Singapore Stewardship Principles for Responsible Investors, an industry-led initiative that sets out seven principles for "fostering good stewardship ... and creating sustainable long-term value for all stakeholders" (Stewardship Asia 2019).

\section{Viet Nam}

In accordance with the National Green Growth Strategy and the National Action Plan on Green Growth between 2014 to 2020, the State Bank of Vietnam (SBV) has been assigned to lead the institutional improvement and capacity building in the banking sector for green growth. In 2015, the SBV issued Directive No. 3 on promoting green credit growth and incorporating ESRM in lending operations, and Decision No. 1552 on the issuance of an action plan for the banking sector to contribute to the National Green Growth Strategy to 2020. The directive required the banking sector to consider "protecting the environment, improving the efficiency of the utilization of natural resources and energy; improving environmental quality and human health, and ensuring sustainable development" in their lending operations. Under the Directive, the entities at the SBV are asked to coordinate capacity building and monitoring of financial institutions, particularly in the areas of green credit and ESRM. Financial institutions have also been required to develop green credit policy to increase the share of green credit in their portfolio, to formulate and execute ESRM in their credit granting activities and to report their green activities to SBV on quarterly basis. The 2015 directive paved the way for further developments in sustainable and green banking in Viet Nam.

After the issuance of the 2015 directive, the SBV introduced a number of complementary initiatives to accelerate sustainable banking in Viet Nam. In 2016, the SBV issued a circular which emphasises that one of the main lending principles for customers and transactions is to comply with environmental laws and regulations. In 2017, the SBV launched the Green Project Catalogue which defines green projects and sectors and the Master Credit Program that provides a framework to incentivise green projects in terms of rates and terms. In August 2018, the SBV issued Decision No. 1640, which put forward a scheme to develop green banking in Viet Nam. The scheme aims to gradually increase the share of credit extension to green 
projects as defined in the Green Project Catalogue, to accelerate the application of green technologies in banking operations, and to ensure that by 2025 all banks will issue their internal regulations on ESRM and integrate the environmental risk assessment as part of their overall credit risk assessment. The initiatives taken by the SBV thus far reflect the commitment of the regulator to steer the country, and particularly the banking sector, towards a greener economy.

\section{Conclusions and Recommendations}

Central banks and monetary authorities across the Asia-Pacific region show an increasing awareness of the need to address climate-related risks in financial markets. The vast majority believe that they should be playing a key role in promoting sustainable finance by capacity building, setting the regulatory framework, encouraging green loans and products and introducing climate change considerations in their monetary and financial policy mandates. Yet the survey results presented in this paper suggest also very clearly that a majority of central banks and monetary authorities in the Asia-Pacific region are either at an early stage or haven't started yet to address climate and other environmental risk in their operations. The majority of authorities have not put in place any capacity building or training programmes for their staff or the external financial community. At the same time, our review of activities of central banks (as well as other financial authorities) in six Asia-Pacific countries has shown that some central banks and monetary authorities in the region have been amongst those leading the discourse and practice in addressing climate and environmental risk. The number of regional meetings, conferences and seminars on climate risk and green finance that are organised or supported by central banks, continues to increase.

Given the survey responses above, clearly there is appetite from central banks and monetary authorities in the Asia-Pacific region to take further measures to promote green and low carbon financing. Promoting awareness and capacity building are clearly important first steps. There are a number of actions being discussed by central banks and supervisors globally to respond to climate-related financial risks, not least through the work of the NGFS. So, what should form the way forward for central banks and monetary authorities in the Asia-Pacific, from a policy and implementation perspective? In the following, we discuss some of the main actions that central banks and supervisors should consider.

Under the Basel III regulatory framework, low-carbon lending would generally be considered as higher risk, given that facilities typically have longer tenors, face higher refinancing risks and lower liquidity, and may be vulnerable to policy changes. Conversely, the Basel framework does not explicitly account for the greater risks of lending to carbon-intensive ventures, and hence these profit from an implicit benefit. In order to bridge this gap, supervisors may introduce brown-penalising or green-supporting factors that could be applied to capital requirement calculations. As discussed above, the PRC has already implemented such a framework whith lower capital requirements for green bank loans compared to other types of lending. However, such an approach is not without risk: lowering capital requirements for bank loans to lowcarbon industries could incentivise greater risk-taking in those sectors, with the risk of fostering a "green bubble". A better approach would be to introduce carbon-based capital buffers that would apply to lending to carbon-intensive activities. This would remove some of the inherent biases in the system towards lending to carbon-intensive industries, whilst facilitating lowcarbon lending and avoiding some of the pitfalls described above. 
A further tool for supervisors to address climate-related risk is stress testing. Modelling different climate scenarios that reflect a variety of transition paths to a low-carbon economy can help to gauge the potential impact of climate change on individual firms and financial system stability at large. In the UK, the Bank of England and its Prudential Regulation Authority have already announced to include climate stress testing as part of their annual Concurrent Stress Testing process. Although climate stress tests involve complex challenges around how to model climate-related scenarios, as well as assessing the impact of related second order effects, they provide critical information for both supervisors and supervisees. Mandatory climate stress testing will require banks and financial institutions to carefully consider climate risks. Once climate stress scenarios are on the agenda and are being taken seriously by regulatory bodies and the firms they regulate, it will force greater expertise to be developed through increased practice and need. Over time, more robust modelling approaches will develop.

For both supervisors and supervisees to adequately properly assess climate risks, it will be necessary to enhance data availability. The quality of risk analysis will increase with greater sophistication in data collection, extraction and analysis techniques. To this end, it will be imperative to make climate-related financial disclosure reporting mandatory. The TCFD recommendations provide an excellent framework which is increasingly being taken up by supervisory bodies.

Furthermore, central banks can support the development of sustainable capital markets and promote green / low-carbon financing options. Central banks and monetary authorities can help to facilitate capital market access for green bond issuers, assist in reducing borrowing and/or issuance costs, or indeed invest in the green bond market themselves.

Last but not least, given that climate change is a common threat, there is scope and a strong case for regional and global cooperation in addressing climate risk and scaling up sustainable finance. At the global level, the NGFS has emerged as the main platform for central banks and supervisors to jointly discuss the best ways forward in addressing climate and environmental risk, scaling up sustainable finance, and - importantly - sharing best practices. More central banks across the Asia-Pacific region should consider joining the NGFS and actively participate in the discussions that are going to set standards in one of the crucial future areas of central banking. There is also a strong case for fostering regional cooperation in the Asia-Pacific region or its various sub-regions. ASEAN provides a good example that should be developed further. ASEAN countries, which have developed an agenda for regional financial cooperation and integration, have already agreed on ASEAN Green Bond Standards, which were published by the ASEAN Capital Markets Forum in November 2017 (ACMF, 2017).

Summing up, there are multiple ways central banks and monetary authorities can actively address climate-related financial risks and support the scaling up of sustainable finance. Once climate change is accepted as a prudential risk, and there is ample evidence that it should be, there are several policy options for central banks and supervisory authorities. The decision on what actions to take and how far to go down the path of encouraging low carbon financing will be ones that will need to be debated and discussed carefully, taking into consideration the country-specific context. In the end it will clearly be up to each individual nation, their governments and their institutions, to elect where they wish to sit along the line of potential actions. What is clear, however, is that not taking any action at all on the prudential risks associated with climate change is no longer a viable option. 


\section{References}

ACMF (2017), ASEAN Green Bond Standards, Jakarta: ASEAN Capital Markets Forum.

Batten S., R. Sowerbutts and M. Tanaka (2016), "Let's Talk about the Weather: The Impact of Climate Change on Central Banks." BoE Working Paper No. 603. London: Bank of England.

Campiglio, E., Y. Dafermos, P. Monnin, J. Ryan-Collins, G. Schotten and M. Tanaka (2018), "Finance and Climate Change: What Role for Central Banks and Financial Regulators?" Nature Climate Change 8, 462-468.

CBI (2019), Green Infrastructure Investment Opportunities: Indonesia, London: Climate Bonds Initiative.

Cœuré, B. (2018), "Monetary Policy and Climate Change." Speech at a conference on "Scaling up Green Finance: The Role of Central Banks" organised by the Network for Greening the Financial System, the Deutsche Bundesbank and the Council on Economic Policies, Berlin, 8 November, https://www.ecb.europa.eu/press/key/date/2018/html/ecb.sp181108.en.html

Dikau, S. and U. Volz (2019a), "Central Banking, Climate Change and Green Finance", in: J. Sachs, W. Thye Woo, N. Yoshino, and F. Taghizadeh-Hesary (eds.), Springer Handbook of Green Finance: Energy Security and Sustainable Development, New York: Springer, pp. 81-102.

Dikau, S. and U. Volz (2019b), "Central Bank Mandates, Sustainability Objectives and the Promotion of Green Finance", SOAS Economics Working Paper No. 222, London: SOAS University of London.

McKibbin, W.J., A.C. Morris, A. Panton and P. Wilcoxen (2017), "Climate Change and Monetary Policy: Dealing with Disruption", Climate and Energy Economics Discussion Paper, Washington, DC: Brookings Institution.

NGFS (2019), A Call for Action. Climate Change as a Source of Financial Risk. Paris: Network for Greening the Financial System.

Stewardship Asia (2019), Singapore Stewardship Principles", URL: https://www.stewardshipasia.com.sg/intent

TCFD (2017), Final Report: Recommendations of the Task Force on Climate-related Financial Disclosures, Basel: Task Force on Climate-related Financial Disclosures, URL: https://www.fsbtcfd.org/wp-content/uploads/2017/06/FINAL-2017-TCFD-Report-11052018.pdf

TCFD (2019), 2019 Status Report, Basel: Task Force on Climate-related Financial Disclosures, https://www.fsb-tcfd.org/wp-content/uploads/2019/06/2019-TCFD-Status-Report-FINAL053119.pdf

Volz, U. (2015), Towards a Sustainable Financial System in Indonesia. Geneva: UNEP Inquiry into the Design of a Sustainable Financial System.

Volz, U., J. Böhnke, V. Eidt, L. Knierim, K. Richert and G.-M. Roeber (2015), Financing the Green Transformation - How to Make Green Finance Work in Indonesia. Houndmills, Basingstoke: Palgrave Macmillan.

Volz, U. (2017), "On the Role of Central Banks in Enhancing Green Finance", Inquiry Working Paper No. 17/01, Geneva: UNEP Inquiry into the Design of a Sustainable Financial System. 
Volz, U. (2019), "Fostering Green Finance for Sustainable Development in Asia", in U. Volz, P. Morgan and N. Yoshino (eds.), Routledge Handbook of Banking and Finance in Asia, London: Routledge, pp. 488-504. 
Figure 1: Responses to survey questions 1-4

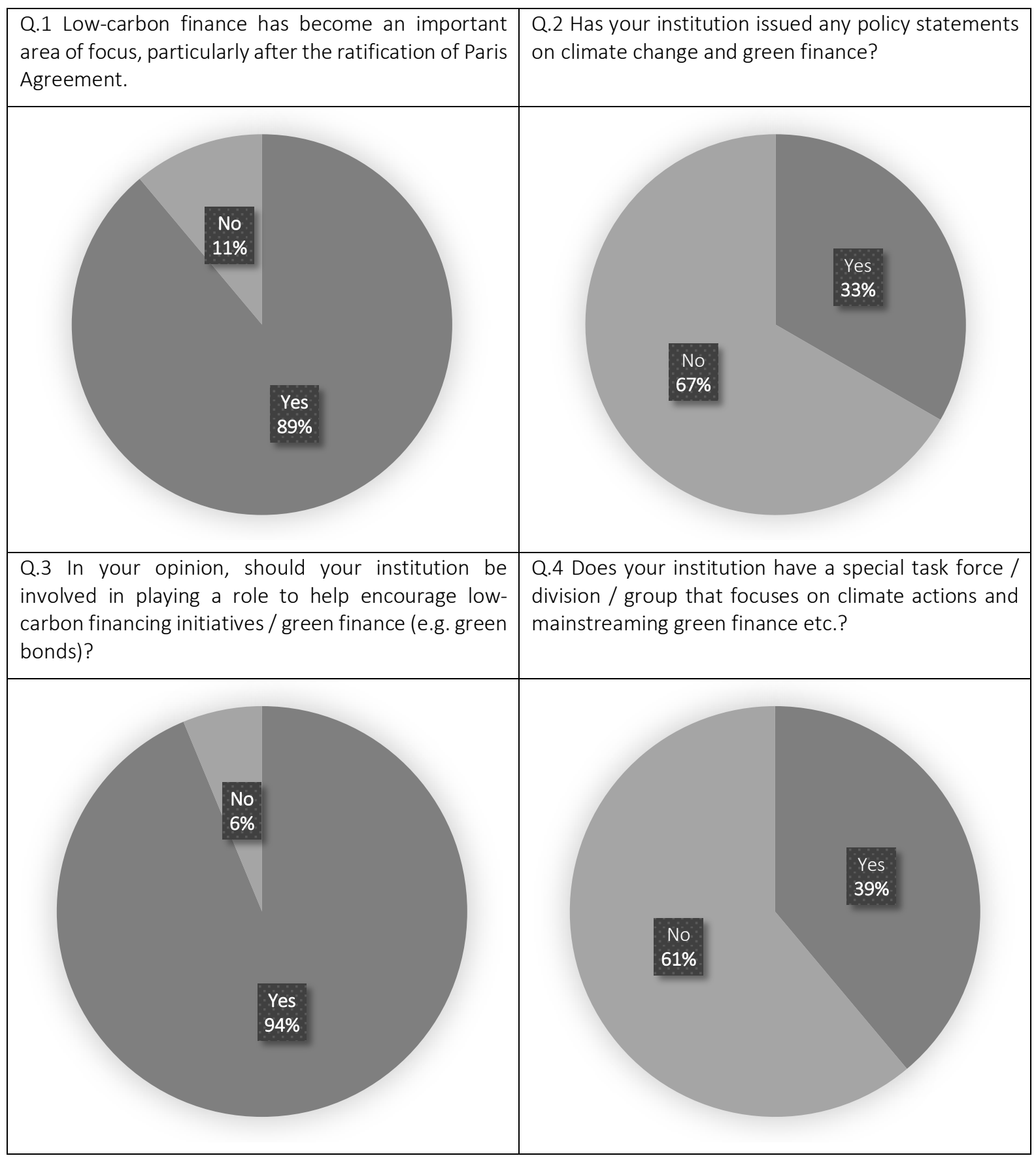

Source: SEACEN Survey, 2019: Q2. 
Figure 2: Responses to survey question 5

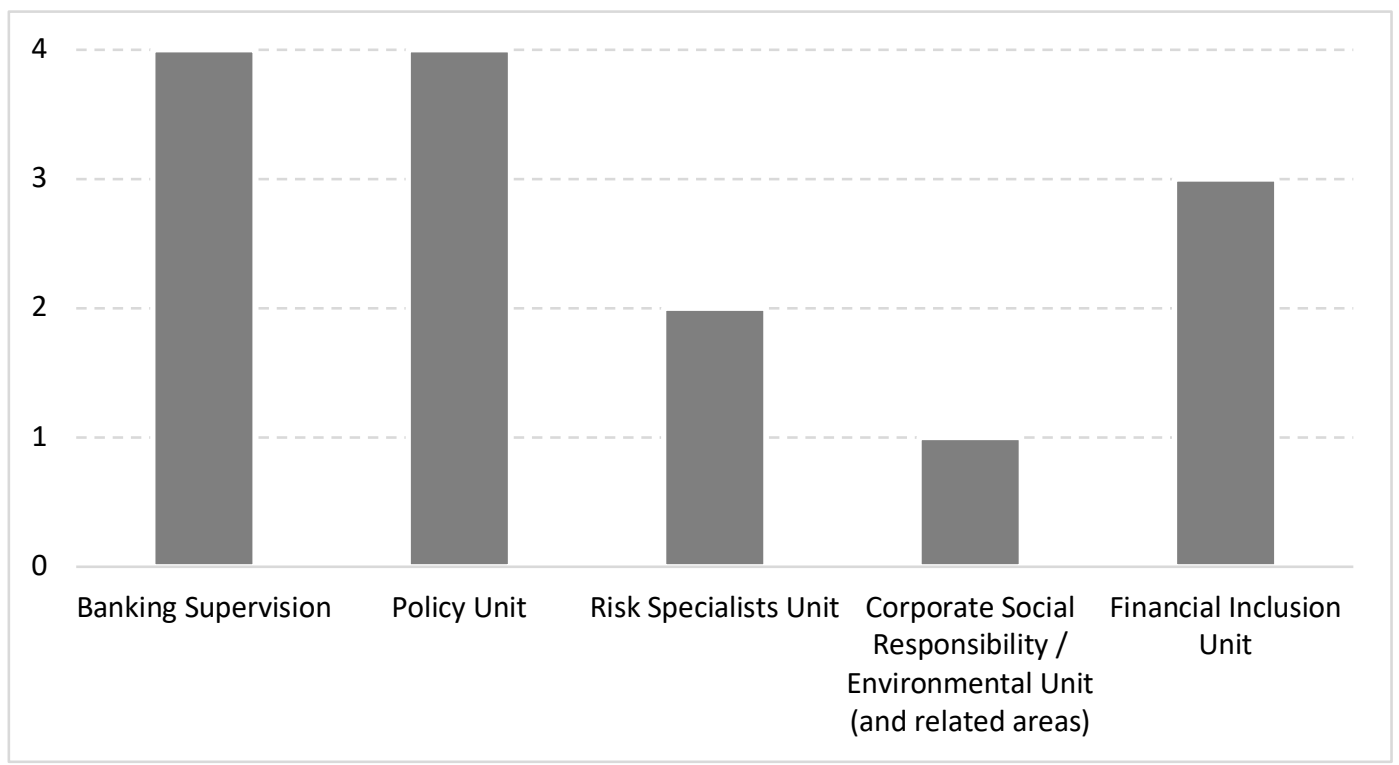

Source: SEACEN Survey, 2019: Q2. 
Figure 3: Responses to survey questions 6-9

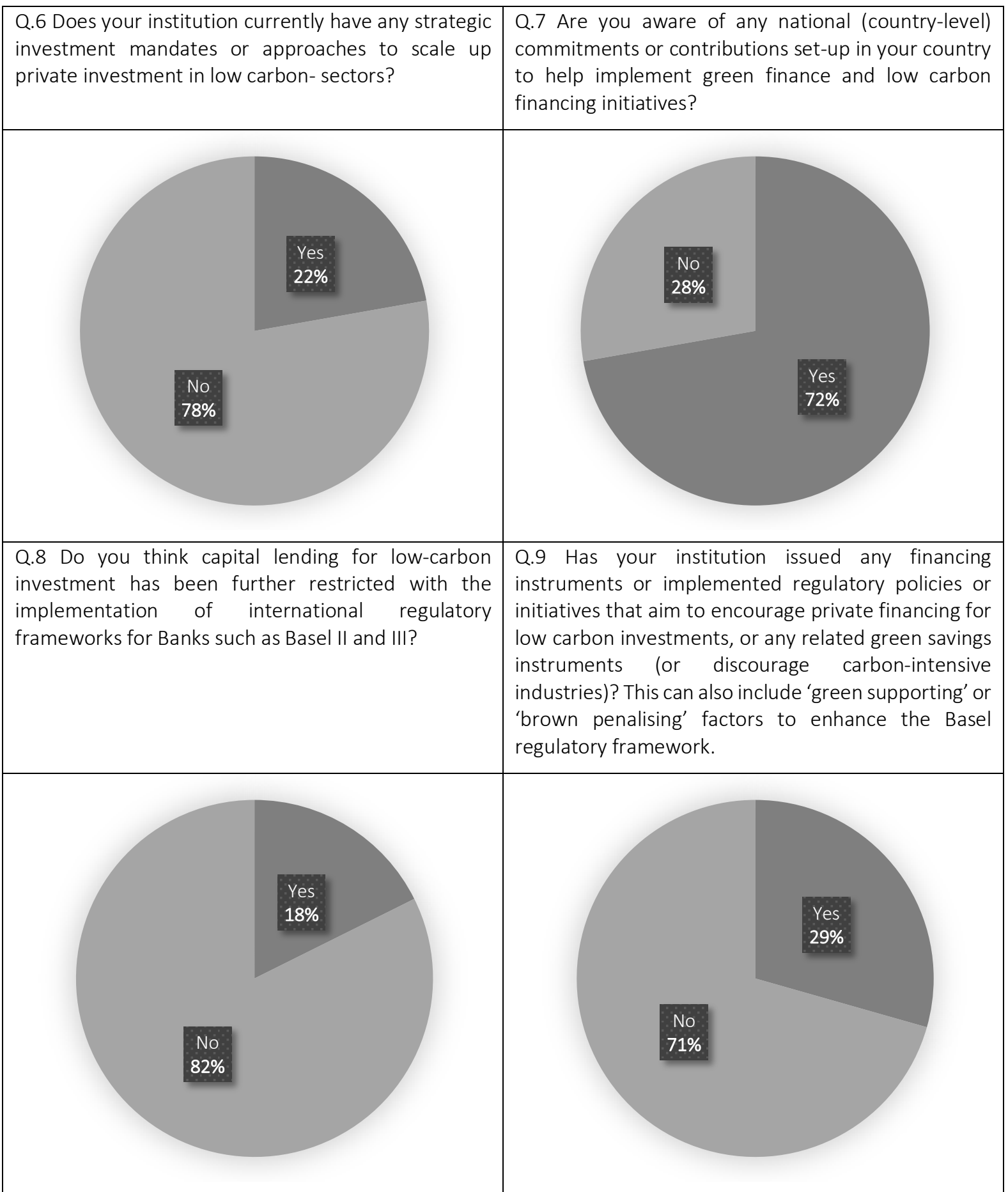

Source: SEACEN Survey, 2019: Q2. 
Figure 4: Responses to survey questions 10-13

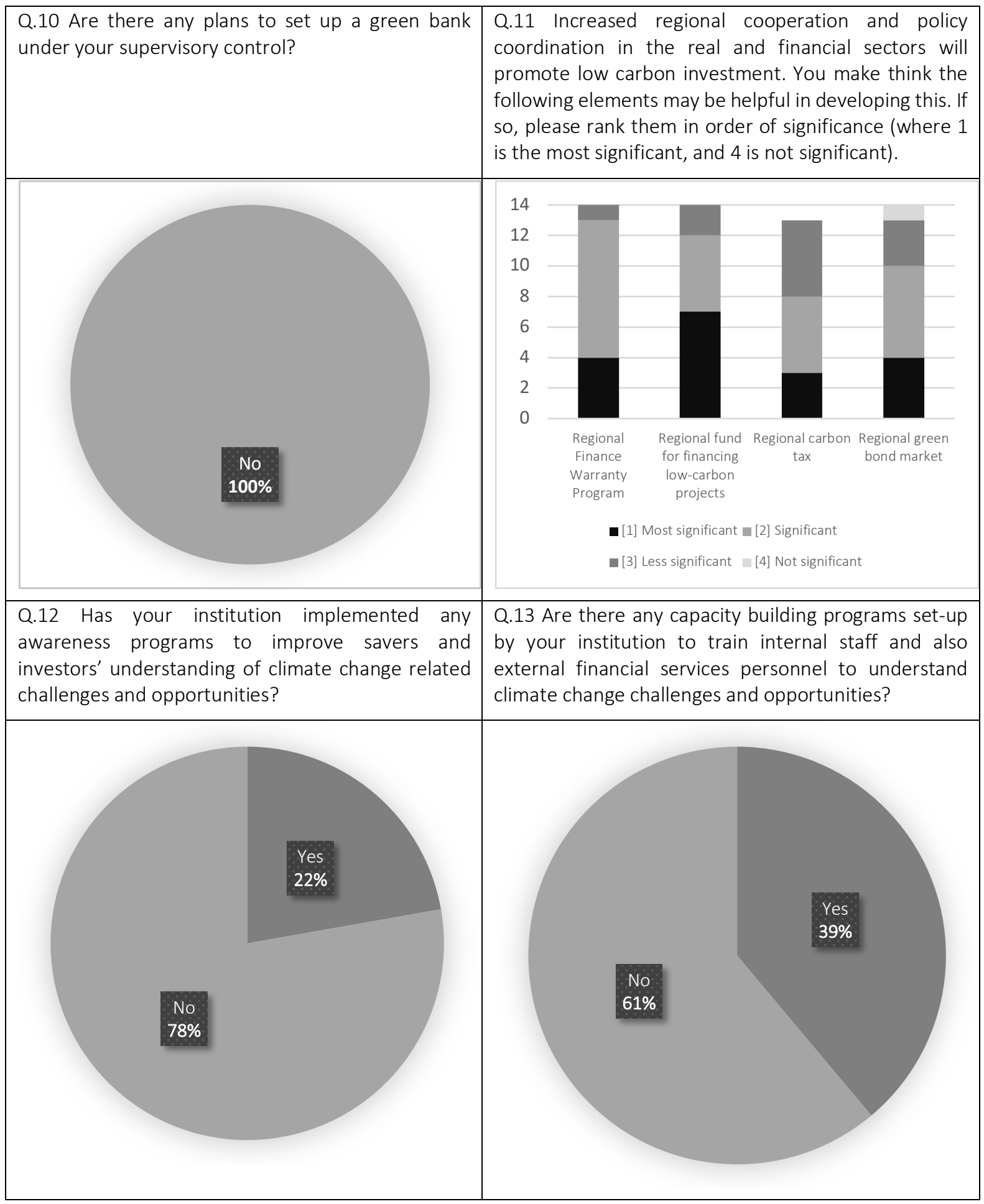

Source: SEACEN Survey, 2019: Q2. 